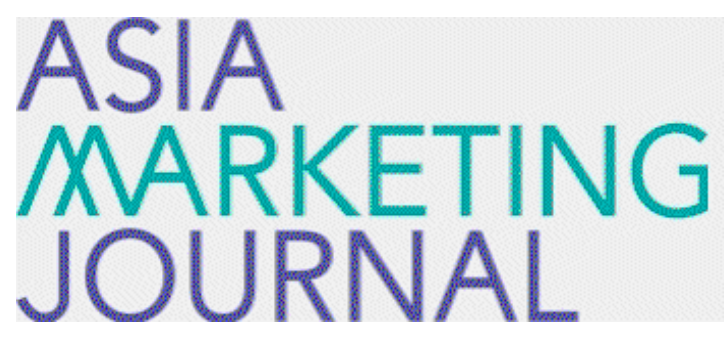

ASIA MARKETING JOURNAL

Volume 16 | Issue 1

Article 10

4-30-2014

\title{
The Impacts of Changes in Brand Attributes on Financial Market Valuation of Korean Firms
}

Hee Tae Lee

Byung Do Kim

Follow this and additional works at: https://amj.kma.re.kr/journal

Part of the Marketing Commons

\section{Recommended Citation}

Lee, Hee Tae and Kim, Byung Do (2014) "The Impacts of Changes in Brand Attributes on Financial Market Valuation of Korean Firms," Asia Marketing Journal: Vol. 16 : Iss. 1 , Article 10.

Available at: https://doi.org/10.53728/2765-6500.1533

This Article is brought to you for free and open access by Asia Marketing Journal. It has been accepted for inclusion in Asia Marketing Journal by an authorized editor of Asia Marketing Journal. 


\title{
The Impacts of Changes in Brand Attributes on Financial Market Valuation of Korean Firms*
}

\author{
Hee Tae Lee** \\ Byung-Do Kim***
}

The earlier studies have verified that brand values have significant impact on financial values such as stock return and stock price to justify marketing costs for brand building. Except for Mizik and Jacobson (2008), however, little research has addressed what kinds of brand components composing brand values have a significant relationship with financial values. As a follow-up research of Mizik and Jacobson (2008), this research focuses on what kinds of relationships exist between the unanticipated change of each brand asset component and stock return, one of the financial values. The authors selected six brand asset components from the Korea-Brand Power Index (K-BPI) data in which 'Top of Mind,' 'Unaided Awareness,' and 'Aided Awareness' are brand awareness measures and 'Image,' 'Purchase Intention,' and 'Preference' are brand loyalty measures. Out of those six brand components, they found that unanticipated changes of 'Top of Mind, 'Unaided Awareness,' 'Image,' and 'Preference' have significantly positive effect on unexpected stock return change. Therefore, they conclude that these four brand asset components provide incremental information in explaining unanticipated stock return.

Key words: brand asset component, financial value, stock return, the Efficient Market Hypothesis(EHM)

\section{Executive Summary}

The existing studies have proved that brand values have significant impact on financial values such as stock return and stock price. Except for Mizik and Jacobson (2008), however, little research has dealt with the question that what kinds of brand components composing brand values have a significant impact on financial values. Thus, this research focuses on what kinds of relationships exist between the unanticipated change of each brand asset component and stock return as a follow-up research of Mizik and Jacobson (2008).

\footnotetext{
* This research was funded by Management Research Center in the Business School, Seoul National University

** Doctoral student, College of Business Administration, Seoul National University(qmre@daum.net), Corresponding author

*** Dean, College of Business Administration, Seoul National University(bxk@snu.ac.kr)
} 


\section{Research Methods}

Using the brand equity data from the KoreaBrand Power Index (K-BPI) combined with accounting and financial market panel data, we conducted our research using the Stock Return Response Model (SRRM).

$$
\begin{aligned}
\operatorname{STR}_{i t}= & \text { Eret }_{i t}+\sum_{j=1}^{J} \varphi_{j} U \Delta A c P_{j i t} \\
& +\sum_{k=1}^{K} \beta_{k} U \Delta \text { Brandasset }_{k i t}+\varepsilon_{i t}
\end{aligned}
$$

$S T R_{i t}$ denotes the change rate of market capitalization of current year $t$ over the previous year t-1, Eret $_{i t}$ is the expected profit rate of share firm $\mathrm{i}$ in period $\mathrm{t}, U \Delta A c P_{j i t}$ represents unanticipated changes in accounting measure $\mathrm{j}$ and $U \Delta$ Brandasset $_{\text {kit }}$ stands for unexpected changes in brand characteristic $\mathrm{k}$. We selected six brand asset components from the $\mathrm{K}$-BPI in which 'Top of Mind,' 'Unaided Awareness,' and 'Aided Awareness' are brand awareness measures and 'Image,' 'Purchase Intention,' and 'Preference' are brand loyalty measures.

\section{Contributions and Managerial Implications}

This study reveals that unanticipated changes in 'Top of Mind,' 'Unaided awareness,' 'Brand Image,' and 'Preference (only in the First
Differencing model)' significantly and positively affect stock return. On the other hand, changes in 'Aided Awareness,' and 'Purchase Intention' do not have significant effects on stock return.

The following are key contributions and implications of this study. First, using a unique K-BPI data set, we have proved that some brand components, such as 'Top of Mind,' 'Unaided awareness,' 'Image,' and 'Preferences' are financially valuable. One of the marketing's main contributions is to build intangible brand equity which is time consuming. Thus, the investor community should view marketing spending not as just costs but as a long-term investment. The results of this paper can be helpful to deviate from such short-term perspective of marketing actions and to pursue long-term marketing performance.

Second, the need for public announcements on changes in brand asset value to stock market participants is strengthened by this study since PR and IR managers would be able to realize the financial value of brand assets by their activities. We empirically proved that brand asset components and firm value are positively correlated, which reconfirms the results of related previous studies. Intangible assets such as knowledge and brand are accounting for more and more of the firm's values. Therefore, there will be a growing need for firms to manage brand assets systematically and officially announce the trends of the intangible assets with other tangible asset value periodically, which would 
be beneficial for the investors of the firms.

\section{Research Background}

Ailawadi, Lehmann, and Neslin (2003) regards the brand equity value on customer mindset as unattractive due to the fact that it is difficult to convert the value into monetary value. Despite the difficulty, it's necessary to quantify the brand value in the monetary perspective to justify marketing strategies and activities (Oh 2013). Marketing activities do not function well (Webster, Malter, and Ganesan 2005) and lose their reliability (Rust, Lemon, and Zeithaml 2004) if marketing practitioners fail to measure the financial value of brand asset values.

To prove that brand equity has financial value, some studies have been conducted (Aaker and Jacobson 1994; Aaker and Jacobson 2001; Barth et al. 1998; Mizik and Jacobson 2004). They verified that brand equity has significant financial values in the stock market. However, it might be more practically valuable to verify which brand components are financially important, because a firm can focus on those brand components to build its brand equity. As a follow-up research of Mizik and Jacobson (2008) which found some financially valuable brand components, we examined what kinds of brand components out of brand equity values are correlated with financial values. However, our dataset has more general brand constructs (e.g., brand awareness indicators) in comparison with the dataset of their research. Thus, through this research, marketing practitioners can obtain meaningful implications more readily from the results of our research than from those of their study.

Thus, we intend to empirically analyze the relationship between each component of brand equity and stock returns as the measure of firm value. In detail, this study examines the relationship between the change in each brand component value on the customer's mindset (e.g., brand awareness, loyalty) and the unanticipated change in stock return. We define the value on customer mindset as the annual measure released by a domestic management education and consulting firm. Our approach to analyzing the financial importance of the brand value on the customer's mindset would be of interest to firms establishing brand equity.

The remainder of this paper is organized as follows. Section 2 introduces previous literature on the relationship between brand equity and corporate value. Next, we discuss the model in Section 3. In Section 4, we describe how the data are collected, and Section 5 details the estimation and empirical results. Section 6 concludes our paper with limitations and further research directions. 


\section{Related Literature}

Aaker and Jacobson (1994) assessed the impact of unexpected information regarding perceived quality and salience on stock return by using the Total Research Corporation and EquiTrend Database. The two dimensions are initially suggested by EquiTrend to measure brand equity. They analyzed 102 observations in 34 consumer packaged goods (CPG) industries for 3 years from 1990 to 1992. They concluded that the unexpected change in perceived quality significantly affects the stock return. The unexpected change in salience, however, does not have a significant effect on the stock return. Mizik and Jacobson (2004) extended Aaker and Jacobson's (1994) study and analyzed EquiTrend data from 1990 to 1997 and reached the same results as Aaker and Jacobson (1994). In short, there is a significant and positive relationship between the unpredicted changes in perceived quality and stock returns.

Barth et al. (1998) used a brand equity data provided by Financial World and examined the relationship between brand equity and the rate of rise in stock prices. Their 404 cross sectional time series observations of 183 firms from 1992 to 1996 reveal that the brand equity measure positively affects the stock prices and the percentage rise in stock prices. They found a significant relationship between the brand value evaluated by Financial World and stock price. Aaker and Jacobson (2001) examined the effect of unexpected changes in brand attitudes on stock returns. They focused on consumer brand attitudes on firms in high-tech industries. Techtel Corporation provided 206 observations of 11 firms from 1988 to 1996. The study verifies that the change in brand attitude positively affects stock returns. Aaker and Jacobson (2001) differentiated their study from the previous literature by analyzing the relationship between brand attitudes on firms in high-tech industries and changes in stock returns. Keller (2003) emphasized the importance of brand attitudes by arguing that customer behaviors towards brands (e.g., brand choice) are attributed to brand attitudes. Aaker and Jacobson (2001) supported Keller (2003) by empirically verifying the positive relationship between brand attitudes and firm value.

Mizik and Jacobson (2008) analyzed whether the unexpected change in the 5 Brand Asset Valuator Pillars of Young \& Rubicam (Y\&R) significantly affects the accounting measures that explain stock returns. The five pillars are Differentiation, Relevance, Esteem, Knowledge and Energy. They found that the changes in the perception of Relevance and Energy positively and significantly affect stock returns and provide additional information to the accounting measures. They extended previous studies to investigate the relationship between the changes in customer perceptions on brand 
equity elements and stock returns. While Aaker and Jacobson (1994, 2001) tested their hypotheses with bivariate analysis that might cause omitted variable bias, Mizik and Jacobson (2008) include brand equity measures and accounting performance indices as explanatory variables to address this issue.

〈Table 1〉 describes independent and dependent variables of the previous literature. The variables that provide additional information to significantly explain stock returns are Perceived Quality, Brand Attitude, Brand Value, Relevance, and Energy. The brand characteristics that lead to changes in customer behaviors or forwardlooking and dynamic characteristics are related to changes in stock returns as composite leading indicators.

We choose the Stock Return Response Model which is widely used in previous literature (Aaker and Jacobson 1994; Aaker and Jacobson 2001; Mizik and Jacobson 2004, Mizik and
Jacobson 2008 ). However, this research differs from previous studies in three aspects. First, the unique Korean brand asset components dataset used in this study helps researchers to compare the results from various empirical studies. Our brand equity data consists of 3 brand awareness and 3 brand loyalty components which cannot be readily obtained from other datasets. In addition, our data can generate generally applicable results because it uses panel data that covers extensive brands accumulated for 8 years since 2001 which are more general constructs and can provide more applicable implications to firms than 5 pillars of $Y \& R$ in Mizik and Jacobson (2008).

Second, as a follow-up study of Mizik and Jacobson (2008), this research can provide valuable managerial implications on brand equity management since we empirically analyzed the relationship between each component of brand equity and the stock returns as the measure of

$\langle$ Table 1〉 Variables in Previous Research

\begin{tabular}{c|l|l|l|l}
\hline \multicolumn{1}{c|}{ Paper } & \multicolumn{1}{|c|}{$\begin{array}{c}\text { Significant IV } \\
\text { (Brand Equity) }\end{array}$} & $\begin{array}{c}\text { Significant IV } \\
\text { (Accounting Performance) }\end{array}$ & $\begin{array}{c}\text { Statistically } \\
\text { Nonsignificant IV }\end{array}$ & DV \\
\hline \hline $\begin{array}{c}\text { Aaker \& Jacobson(1994) } \\
\text { Mizik \& Jacobson(2004) }\end{array}$ & Perceived quality & ROI & $\begin{array}{l}\text { Salience, } \\
\text { Advertising }\end{array}$ & Stock Return \\
\hline Aaker \& Jacobson(2001) & $\triangle$ Brand attitude & $\triangle \mathrm{ROE}$ & & Stock Return \\
\hline \multirow{2}{*}{ Barth et al.(1998) } & Brand Value & Book Value, Net Income & & Stock Price \\
\cline { 2 - 5 } & $\triangle$ Brand Value & Net Income & $\triangle$ Net Income & Stock Return \\
\hline \multirow{3}{*}{ Mizik \& Jacobson(2008) } & $\begin{array}{l}\Delta \text { Relevance, } \\
\text { Energy }\end{array}$ & $\begin{array}{l}\mathrm{U} \triangle \mathrm{ROA} \\
\mathrm{U} \triangle \mathrm{EPS}\end{array}$ & $\begin{array}{l}\triangle \text { Differentiation } \\
\mathrm{U} \triangle \text { Esteem } \\
\triangle \text { Knowledge } \\
\text { Factor } 1 \sim 8\end{array}$ & Stock Return \\
\hline
\end{tabular}

* IV: Independent Variable, DV: Dependent Variable

* $\triangle$ denotes the increment in the corresponding period 
firm value. Barth et al. (1998) examined the relationship between stock returns and brand equity calculated from the weighted sum of each brand component and identified statistically significant and positive effects of brand equity on stock prices. The studies, however, cannot discover which components of brand value contribute to changes in stock returns. Thus, they do not provide sufficient and detailed managerial implications on brand management although, they verified the financial value of brand equity

Lastly, although previous studies including Mizik and Jacobson (2008) used just Fixed Effects Model with their panel data, we applied First Differencing model as well as Fixed Effects model.

\section{Model}

This research mainly analyzes data with the Stock Return Response Model (SRRM) to measure financial value of brand asset components (See Mizik and Jacobson (2008) for details of Stock Return Response Model).

Changes in accounting measures might still affect stock returns since present financial statements do not entirely reflect the impact of changes in brand assets on cash flows. That is, the stock investor's evaluation on the impact of brand asset value on future cash flows would influence future firm value and share prices. Abnormal stock returns can be attributed to unanticipated changes in accounting measures and brand assets, which is given by

$$
\begin{aligned}
& \operatorname{STR}_{i t}-\text { Eret }_{i t}=\sum_{T=t}^{\infty}\left(\frac{1}{1+r_{i t}}\right)^{T-t} \frac{\Delta E\left(C F_{i T}\right)}{M k t C a p_{i t-1}} \\
& =\sum_{j=1}^{J} \varphi_{j} U \Delta A c P_{j i t}+\sum_{k=1}^{K} \beta_{k} U \Delta \text { Brandasset }_{k i t}+\varepsilon_{i t}
\end{aligned}
$$

$$
\text { where } \operatorname{STR}_{i t}=\frac{M k t C a p_{i t}-M k t C a p_{i t-1}}{M k t C a p_{i t-1}} \text { and } \text { Eret }_{i t}
$$

is the expected profit rate of share firm $i$ in

period t. $\sum_{T=t}^{\infty}\left(\frac{1}{1+r_{i t}}\right)^{T-t} \frac{\Delta E\left(C F_{i T}\right)}{M k t C a p_{i t-1}}$ denotes abnormal profit rates and $M k t C a p_{i t}$ represents Market Capitalization ${ }^{1)}$ of firm $\mathrm{i}$ in period t. $r_{i t}$ stands for discount rate of firm $i$ in period $t$ and $\triangle E\left(C F_{i T}\right)$ is the changes in expectation on cash flows in period t. $U \Delta A c P_{j i t}$ shows unanticipated changes in accounting measure $\mathrm{j}$ and UABrandasset kit $_{\text {it }}$ stands for those in brand characteristic $\mathrm{k}$. In other words, abnormal stock returns denoted as $\sum_{T=t}^{\infty}\left(\frac{1}{1+r_{i t}}\right)^{T-t} \frac{\Delta E\left(C F_{i T}\right)}{M k t C a p_{i t-1}}$ $=f\left(U \Delta A c P_{j i t}, U \Delta\right.$ Brandasset $\left._{\text {kit }}\right)$ are a function of unanticipated changes in accounting measures and brand characteristics. Equation (1)

1) Market Capitalization is the product of market value and the number of shares. 
analyzes which brand characteristics are reflected in the financial market apart from accounting performance measures. $\varphi_{j}$ is a $\mathrm{co}^{-}$ efficient of financial performance measures and represents the impact of unanticipated changes in the accounting performance measure $j$ on stock returns. Accounting literature has widely studied the relationship between unanticipated changes in accounting performance measures and firm value (Kothari 2001). $\beta_{k}$ denotes the direct impact of unanticipated changes in brand asset components on stock returns. Significant $\beta_{k}$ implies that brand value measures in addition to accounting measures provide additional explanations on the firm's financial value. The following is a null hypothesis. H0: $\beta_{1}=\beta_{2}$ $=\cdots \beta_{k}=0$ means that unanticipated changes in every brand asset component do not have a significant impact on the firm's financial values.

\section{Data}

This study uses the Korea-Brand Power Index (K-BPI) from Korea Management Association Consulting (KMAC) to determine the components of brand equity that explains the change in the accounting measures, which leads to the change in the stock return. We choose the
$\mathrm{K}$-BPI in this research since the $\mathrm{K}$-BPI evaluates numerous brands of the most extensive industries and is known to be a reputable brand power index by firms for the longest period in Korea. Our panel data is obtained by matching the financial and stock prices data with the brand value data of the listed companies. This study runs regressions on the panel data.

\subsection{K-BPI}

KMAC announced the first K-BPI result survey in 1999. The K-BPI is the indexed survey results of the brand value of firms in major domestic industries from the perspective of customers (Park 2003, p153-56). KMAC surveyed the brand value of 2,095 brands in 79 industries in 1999 and extended the scope of their investigation to 192 industries in 2009. The survey design is described in Table 2.

The $\mathrm{K}-\mathrm{BPI}$ is calculated by combining brand awareness and brand loyalty ${ }^{2)}$ from the customer's cognitive view. Awareness and loyalty have been weighted as $80 \%$ and $20 \%$, respectively until 2000, when they were changed to $70 \%$ (Top of Mind 40\%, Unaided Awareness 20\%, Aided Awareness 10\%) and 30\%, respectively. The new weight values reflect that researchers put more emphasis on brand loyalty, and the qualitative aspect of brand value. Moreover,

2) There might be some controversy over whether brand image, purchase intention and preference are components of brand loyalty. Moreover, brand loyalty and brand equity are generally viewed as conceptually separated. See Jun and Park (2010) for details. 
〈Table 2〉 K-BPI Survey Design

\begin{tabular}{c|l}
\hline Subject & Korean consumers aged from 15 to 60 \\
\hline Site & Seoul and 6 Metropolitan Cities in Korea(Inchon, Busan, Daegu, Ulsan, Daejeon, Gwangju) \\
\hline Sampling & Random Sampling proportional to population (by gender, age, site) \\
\hline Sample Size & 11,272 \\
\hline Period & About 3 month at the end of every year \\
\hline Method & Individual interview with researchers who visit subjects one by one \\
\hline Industry & 192 \\
\hline
\end{tabular}

the result is normalized and scored out of 1,000 (please refer to Table 3,4).

This research uses brand characteristic data (Top-of-Mind Awareness, Unaided Awareness, Aided Awareness, Image, Purchase Intention,
Preference) that are components of the K-BPI. We obtained data on accounting performances and brand equity characteristics from two sources, which is detailed in $\langle$ Table 5$\rangle$. KMAC provides brand awareness and loyalty data that are a

〈Table 3〉 K-BPI Computation

$$
\mathrm{K}-\mathrm{BPI}=1,000(.4 \times X 1+.2 \times X 2+.1 \times X 3+.3 \times X 4)
$$

$\mathrm{XI}=$ Top of Mind, $\mathrm{X} 2=$ Unaided Awareness, X3=Aided Awareness,

$\mathrm{X} 4=\mathrm{Z}$-score (the weighted average of Brand Loyalty, Purchase Intention, Preference with the weight of 3,4 and 3 , respectively)

〈Table 4〉 K-BPI Components

\begin{tabular}{|c|c|c|c|}
\hline \multicolumn{2}{|c|}{ Component } & Details & Score \\
\hline \multirow{3}{*}{\multicolumn{2}{|c|}{ Awareness }} & Top of mind Awareness & 400 \\
\hline & & Unaided Awareness & 200 \\
\hline & & Aided Awareness & 100 \\
\hline \multirow{9}{*}{ Loyalty } & \multirow{4}{*}{$\begin{array}{l}\text { Brand } \\
\text { Image }\end{array}$} & 1) This brand has a high value for its price. & \multirow{4}{*}{90} \\
\hline & & 2) This brand is a unique one. & \\
\hline & & 3) This brand is a lively one. & \\
\hline & & 4) This brand is a trustworthy one. & \\
\hline & \multirow{3}{*}{$\begin{array}{l}\text { Purchase } \\
\text { Intention }\end{array}$} & 5) I am willing to purchase/use this brand in large discount stores. & \multirow{3}{*}{120} \\
\hline & & 6) I am willing to recommend this brand to others. & \\
\hline & & 7) This brand is easy to purchase everywhere. & \\
\hline & \multirow{2}{*}{ Preference } & 8) I like this brand. & \multirow{2}{*}{90} \\
\hline & & 9) Others like this brand. & \\
\hline \multicolumn{2}{|c|}{ Total } & & 1,000 \\
\hline
\end{tabular}


part of the K-BPI and Dataguide pro in Fnguide (www.fnguide.com) which provides accounting indices. This research uses Return on Asset (ROA) and Sales as accounting performance measures and analyzes 6 brand characteristics of the K-BPI as brand equity measures.

The K-BPI consumer survey has been conducted since 1999, but has established its current components as in 〈Table 3$\rangle$ in 2001. Thus this study uses data from 2001 (to 2008) for data consistency. We analyze only the brands of firms which are listed on Korea Stock Exchange (KSE) and Korea Securities Dealers Automated Quotation (KOSDAQ) to investigate the relationship between the brands and the stock returns. Monobrands ${ }^{3)}$ are examined for the one-to-one correspondence of accounting information to brand information. We selected 49 brands based on these criteria from 2001 to 2008 as in 〈Table 6〉. This study analyzes unbalanced panel data which includes missing data to avoid Survivorship bias ${ }^{4)}$

\subsection{Accounting Performance}

The quarterly net income and annual sales data (as of Dec. 31) from 2001 to 2008 are collected based on Easton and Harris (1991) and Kothari (2001), respectively from Dataguide pro.

〈Table 5〉 Data Sources and Measures

\begin{tabular}{l|l|c}
\hline \multicolumn{1}{c|}{ Source } & \multicolumn{1}{|c}{ Measure } & Collection Period \\
\hline \hline KMAC & $\begin{array}{l}\text { K-BPI Data: Individual brand characteristics, } \\
\text { Awareness (Top-of-mind, Unaided, Aided), }\end{array}$ & Year \\
& Loyalty (Image, Purchase intention, Preference) & \\
\hline Dataguide pro(fnguide) & Stock Return & Month \\
& ROA(=Net profit/Total assets) & \\
& Sales Growth & \\
& Book Value(=Total assets-Intangible assets & \\
& -Total liabilities-Preferred Capital Stock) & \\
& Market Value(=Ending Market Capitalization) & \\
\hline
\end{tabular}

Notes: We use the pooled panel data from the two sources.

$\langle$ Table 6〉 The Number of Observed Brands per Year

\begin{tabular}{ccccccccc}
\hline Year & 2002 & 2003 & 2004 & 2005 & 2006 & 2007 & 2008 & Observation \\
$\cdots$ No. & 29 & 32 & 40 & 42 & 45 & 49 & 49 & 286 \\
\hline
\end{tabular}

Notes: Brand asset characteristics variables to be used in this study are differences observed from year 2002. The value of the variable at the year 2002 is the difference between the absolute value at 2002 and the absolute value at 2001 .

3) A monobrand means that one company has just one brand

4) The bias that can occur when companies fail to survive is excluded from the sample 


\subsection{Stock Return}

We acquired monthly stock returns data from January 2000 to December 2008 through Dataguide pro. Annual stock returns in equations (1) and (2) are computed through $S T R_{i t}=$ $\log \left[\prod_{m=k}^{l}\left(1+r e t_{i m}\right)\right]$ (Mizik and Jacobson 2008). $\mathrm{rem}_{i m}$ is firm i's stock return at month $\mathrm{m}$ and $\mathrm{k}$ denotes the first month after year $\mathrm{t}-1$, while 1 denotes the last month at year $t$. This study assumes that $m$ is January and 1 is December. To control for firm-specific characteristics (Fama and French 1993, 1996; Mizik and Jacobson 2008), time-specific intercepts, $\log \left({\left.\text { Market } \text { Value }_{i t-1}\right)}\right.$ ) or $\log M V_{i t-1}$, representing $\log$ of Market Value at the previous year (lagged firm size), and $\log \left(\right.$ BookValue $_{i t-1} /$ MarketValue $\left._{i t-1}\right)$ or $\log B M V_{i t-1}$ demonstrating log of Book Value divided by Market Value of year t-1(lagged book to market equity), are included in the model.

Equation (1) is transformed into equation (2) with the specific variables.

$$
\begin{aligned}
\text {STR }_{i t}= & \text { Eret }_{i t}+\sum_{j=1}^{J} \varphi_{j} U \Delta A c P_{j i t} \\
& +\sum_{k=1}^{K} \beta_{k} U \Delta \text { Brandasset }_{k i t}+\varepsilon_{i t} \\
= & \sum_{t=2002}^{2008} \alpha_{1 t} \times \text { Year }_{t}+\sum_{t=2002}^{2008}\left(\alpha_{2 t} \times \log M V_{i t-1}\right. \\
& \left.+\alpha_{3 t} \times \log B M V_{i t-1}\right) \times \text { Year }_{t} \\
& +\sum_{j=1}^{J} \varphi_{j} U \Delta \text { AcP }_{j i t} . \\
& +\sum_{k=1}^{K} \beta_{k} U \Delta \text { Brandasset }_{k i t}+\varepsilon_{i t}
\end{aligned}
$$

Year $_{t}$ is a dummy variable, which is 1 if observed and 0 otherwise. Also, Eret $_{i}$, expected return, represents $\sum_{t=2002}^{2008} \alpha_{1 t} \times$ Year $_{t}+\sum_{t=2002}^{2008}\left(\alpha_{2 t} \times \log \right.$ $\left.M V_{i t-1}+\alpha_{3 t} \times \log B M V_{i t-1}\right) \times$ Year $t_{t}$ There are two components in $\varepsilon_{i t}$ as $\varepsilon_{i t}=\mu_{i}+\nu_{i t}, \mu_{i} \sim\left(0, \sigma_{\mu}^{2}\right)$, $\nu_{i t} \sim\left(0, \sigma_{t}^{2}\right), \sigma_{\mu}^{2}$ is a firm-specific variance and assumed to be equal across samples. On the other hand, the disturbance term $\sigma_{t}^{2}$ is timevariant and not always equal across samples. $\mu_{i}$ denotes an individual effect that is time-invariant and unobserved. If the individual effect $\mu_{i}$ is irrelevant with explanatory variables, equation (2) is called a random-effects model or called a fixed-effects model otherwise.

\subsection{Unanticipated Measures}

The Efficient Market Hypothesis states that the stock market responds only to unanticipated information thus, the SRRM only reflects unanticipated changes in its explanatory variables. Time-series prediction values are generally used as proxy measures for the expected values and the time-series residuals are used for unanticipated elements. Brand asset components follow random walks (Aaker and Jacobson 1994). That is, unanticipated changes in each brand asset component are represented as $U \Delta$ Brandasset $_{k i t}=$ Brandasset $_{\text {kit }}-$ Brandasset $_{\text {kit }-1}$. The log of sales also follow random walks and the equation $U \Delta$ Sales $_{i t}=\log$ Sales $_{i t}-\log$ Sales $_{i t-1}$ 
computes unanticipated changes in sales.

ROA is the best approximation to a fixed-effects model and the $4^{\text {th }}$-order autoregressive model among accounting performance measures. This study follows Mizik and Jacobson (2008) to compute residuals of $\mathrm{ROA}$ as

$$
\begin{aligned}
& \left(R O A_{i q}-\overline{R O A}_{i q}\right)=\alpha_{i}+\phi_{1} \times \\
& \left(R O A_{i q-1}-\overline{R O A}_{i q-1}\right)+\phi_{2} \times\left(R O A_{i q-2}-\overline{R O A}_{i q-2}\right) \\
& +\phi_{3} \times\left(R O A_{i q-3}-\overline{R O A}_{i q-3}\right)+ \\
& \phi_{4} \times\left(R O A_{i q-4}-\overline{R O A}_{i q-4}\right)+\varepsilon_{i q}
\end{aligned}
$$

and unanticipated changes in ROA as $U \triangle R O A_{i t}$. $R O A_{i q}$ denotes the value of firm is accounting performances at quarter $\mathrm{q}$ and $R O A_{i q-1}, R O A_{i q-2}, R O A_{i q-3}$ and $R O A_{i q-4}$ are lagged values. $\overline{R O A_{i q}}$ is the averaged $\mathrm{ROA}$ of firms in the industry where firm $\mathrm{i}$ belongs to quarter $\mathrm{q}, \alpha_{i}$ is a constant term and $\phi_{k}$ is the kth-order autoregressive parameter. $\varepsilon_{i q}$ from equation (3) is used to compute unanticipated measures through $U \Delta R O A_{i t}=\sum_{q=k}^{l} \varepsilon_{i q}$. Here, k denotes the first quarter after period $t-1$ and 1 denotes the last quarter of period $t$.

〈Table 7〉 presents the descriptive statistics of each variable. 〈Figurel〉 shows the trends of five randomly selected brand asset elements over time. They are ACE BED, CJ HOMESHOPPING, KOREAN AIR, KOOKSOONDANG, HAEPYO. The values of brand asset components of ACE BED, CJ HOMESHOPPING, and KOREAN AIR are rising gradually whereas, the brand value of KOOKSOONDANG is stagnant and that of HAEPYO is slightly decreasing. The Top of Mind brand awareness scores of ACE BED and KOREAN AIR, which are repre-

\begin{tabular}{|c|c|c|c|c|c|}
\hline Variable & Observation & $\mathrm{M}$ & $\mathrm{SD}$ & Min & $\operatorname{Max}$ \\
\hline Str & 270 & -.055 & .660 & -3.077 & 2.375 \\
\hline $\log m v(t-1)$ & 265 & 12.765 & 1.827 & 7.886 & 16.822 \\
\hline $\log b m v(t-1)$ & 261 & -.1353 & .654 & -2.02 & 1.59 \\
\hline$\triangle \mathrm{ROA}$ & 261 & -.001 & .06 & -.383 & .386 \\
\hline$\triangle$ Sales & 274 & .100 & .292 & -1.27 & 1.71 \\
\hline$\triangle$ top of mind & 274 & -.077 & 4.705 & -19.9 & 29.2 \\
\hline$\triangle$ unaided & 274 & .512 & 7.851 & -43 & 37 \\
\hline$\triangle$ aided & 274 & .162 & 7.487 & -44.2 & 35.2 \\
\hline$\triangle$ image & 274 & -.521 & 3.847 & -11.4 & 18.3 \\
\hline$\triangle$ purchase & 274 & .354 & 2.920 & -16.2 & 14.2 \\
\hline$\triangle$ preference & 271 & .244 & 5.052 & -38 & 39.1 \\
\hline
\end{tabular}
sentative brands of bed and aviation industries, are approximately over 70 and the gap between

〈Table 7〉 Descriptive Statistics

Notes: Observation number is different for each variable because the dataset is unbalanced panel. 
〈Figure1〉 Trends of Brand Asset Components over Time for 5 Randomly Selected Brands

\section{ACE BED}

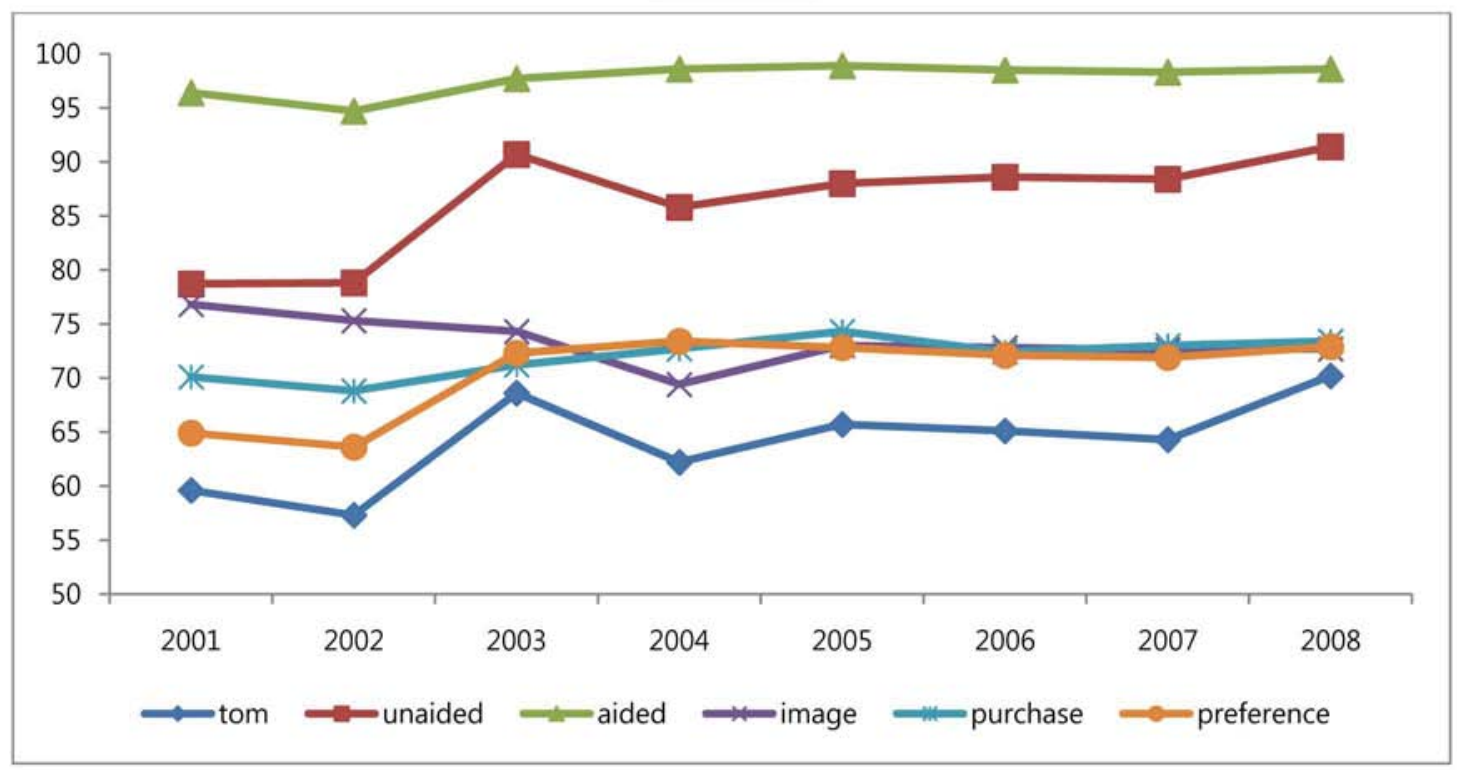

\section{CJ HOMESHOPPING}

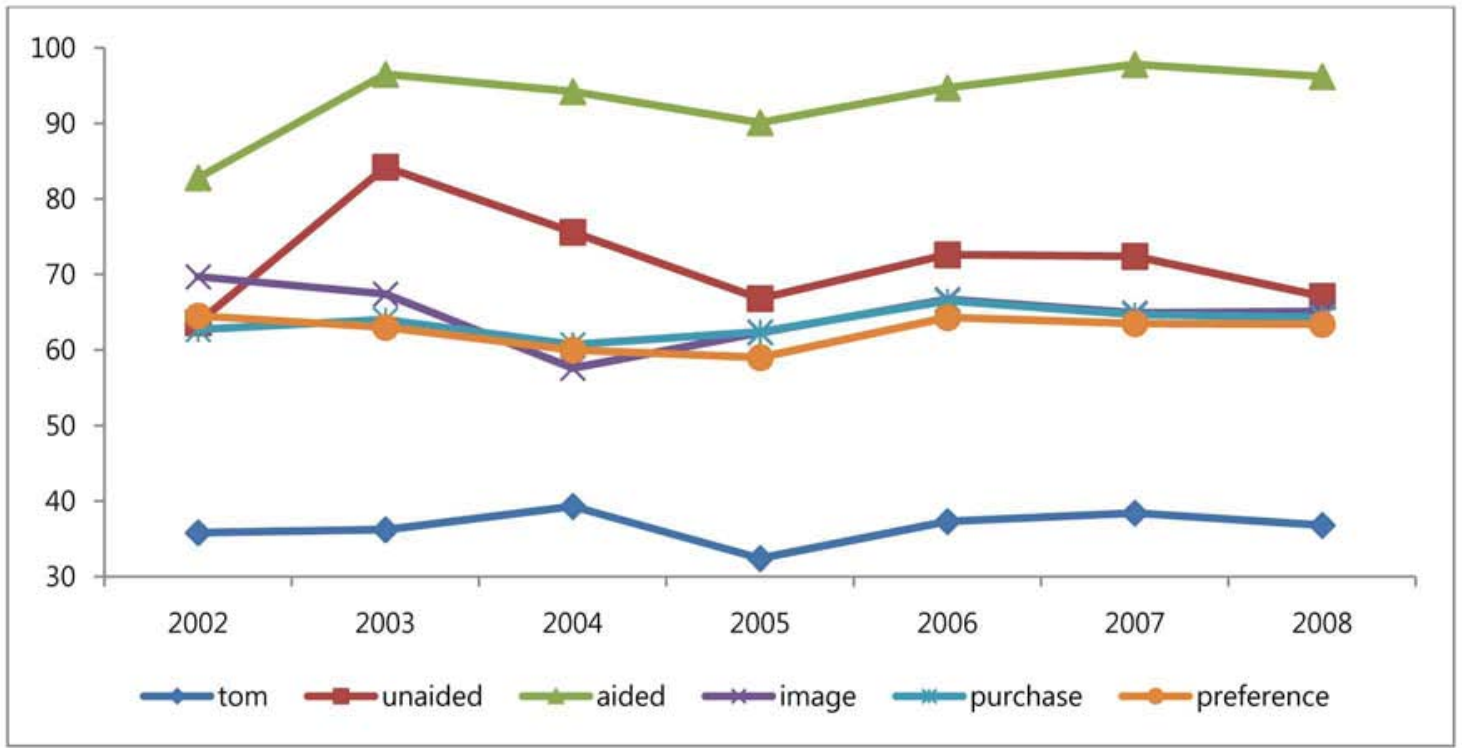

180 ASIA MARKETING JOURNAL Vol. 16 No. 01 April 2014 
〈Figure1〉 Trends of Brand Asset Components over Time for 5 Randomly Selected Brands (continued)

\section{KOREAN AIR}

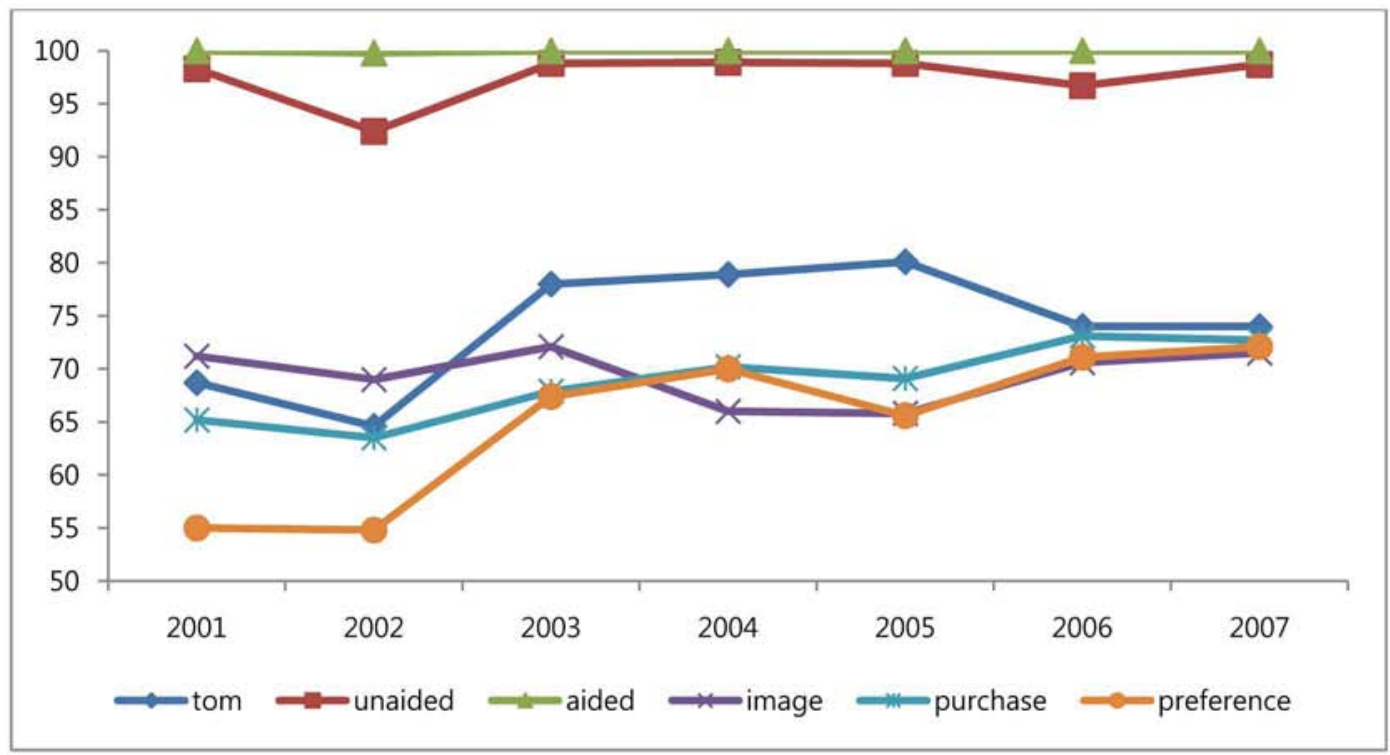

\section{KOOKSOONDANG}

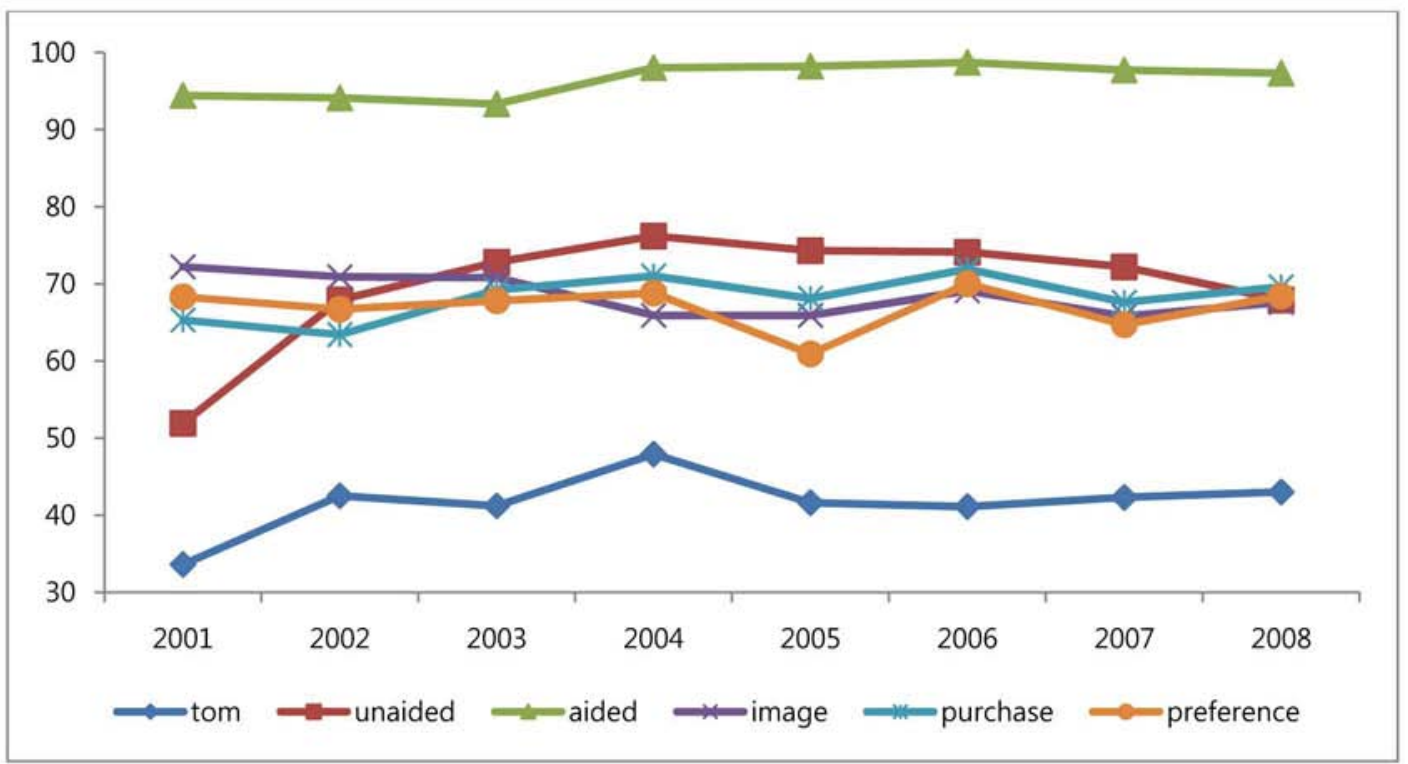


〈Figure1〉 Trends of Brand Asset Components over Time for 5 Randomly Selected Brands (continued)

HAEPYO

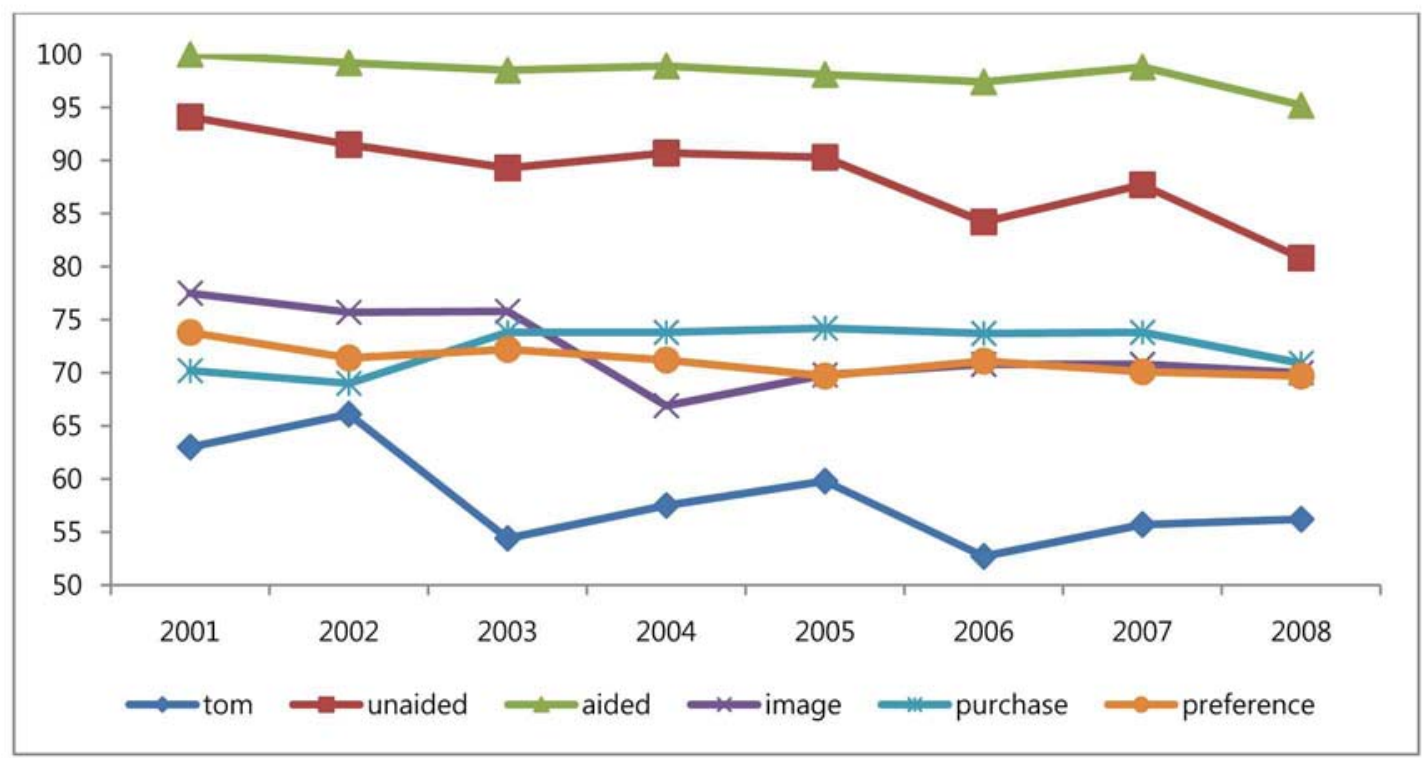

the score of Unaided Brand Awareness and Aided Brand Awareness is small, which inV. Empirical Results dicates that these brands are well managed.

〈Table 8〉 displays the Pearson bivariate correlation analysis results. It shows that significant correlation between brand awareness measures (Top of Mind, Unaided Awareness and Aided Awareness) exist, and that the correlation between loyalty measures (Image, Purchase Intention and Preference) are significantly high.

\subsection{Empirical Analysis}

We run a panel linear regression for data analysis. The Hausman Specification Test (1978) was conducted to make a choice between the random-effects model and the fixed-effects model to estimate equation (2). Through the test, we have found that the fixed effect model is more suitable for our model. ${ }^{5)}$ Thus, we

5) The test statistic $H=\left(\hat{\beta}_{R E}-\hat{\beta}_{F E}\right)^{T}\left(\sum_{F E}-\sum_{R E}\right)^{-1}\left(\hat{\beta}_{R E}-\hat{\beta}_{F E}\right) \stackrel{a}{\sim} \chi^{2}(k)$ follows the chi-squared distribution with degree of freedom k. $\hat{\beta}_{R E}, \hat{\beta}_{F E}, \sum_{F E}, \Sigma_{R E}$ denote estimated coefficient vectors and variance-covariance matrices in the RE model and the FE model. The null hypothesis is "random-effects model is appropriate." That is, this test supports the fixed-effects model if the null hypothesis is rejected and the random-effects model otherwise (Johnston and Dinardo 
〈Table 8〉 Correlation Analysis Results

\begin{tabular}{|c|c|c|c|c|c|c|c|c|c|c|c|}
\hline & Str & $\begin{array}{c}\Delta \text { top of } \\
\text { mind }\end{array}$ & $\Delta$ unaided & $\Delta$ aided & $\Delta$ image & $\Delta$ purchase & $\Delta$ preference & $\triangle \mathrm{ROA}$ & $\Delta$ Sales & $m v(t-1)$ & $b m v(t-1)$ \\
\hline Str & 1 & & & & & & & & & & \\
\hline$\Delta$ top of mind & $.1^{*}$ & 1 & & & & & & & & & \\
\hline$\Delta$ unaided & $.139 * *$ & $-.689 * * *$ & 1 & & & & & & & & \\
\hline$\Delta$ aided & $.137^{* *}$ & $-.334^{* * *}$ & $.547^{* * *}$ & 1 & & & & & & & \\
\hline$\Delta$ image & .091 & .044 & -.035 & .043 & 1 & & & & & & \\
\hline$\Delta$ purchase & -.008 & -.077 & .044 & -.045 & $.590 * * *$ & 1 & & & & & \\
\hline$\Delta$ preference & .073 & -.072 & .023 & $.226^{* * *}$ & $.491 * * *$ & $.512^{* * *}$ & 1 & & & & \\
\hline$\triangle \mathrm{ROA}$ & .1 & .003 & -.020 & .022 & .046 & .013 & .032 & 1 & & & \\
\hline$\Delta$ Sales & .068 & -.018 & -.041 & .029 & $.123^{* *}$ & .090 & .071 & $.174^{* * *}$ & 1 & & \\
\hline$m v(t-1)$ & .001 & -.113 & .037 & .047 & .043 & .026 & .066 & .029 & $.160^{* * *}$ & 1 & \\
\hline $\operatorname{bmv}(t-1)$ & $.257^{* * *}$ & .049 & .059 & -.068 & $-.126^{* *}$ & -.090 & -.061 & $-.108^{*}$ & -.049 & $-.444^{* * *}$ & 1 \\
\hline
\end{tabular}

Notes: 1) str - stock return

2 ) $* * *, * *$ - significant at the $10 \%, 5 \%$ and $1 \%$ level, respectively

run regressions with the fixed-effects (FE) model (See Appendix for detailed specification of the FE model, equation (2')).

The following are the results of FE model. ${ }^{6)}$ A coefficient of unanticipated changes in ROA is found to be statistically significant ( $t$-value 2.26, $\mathrm{p}$-value < .05) which implies that the stock market positively responds to information re- $^{-}$ lated to unanticipated changes in $R O A(\triangle R O A)$. This is consistent with previous studies (Kormendi and Lipe 1987; Mizik and Jacobson 2008).
This research mainly focuses on whether unanticipated changes in 6 brand equity components of the K-BPI provide additional explanations on accounting measures when they are related to abnormal stock performances. 〈Table 9〉 indicates that unanticipated changes in Top of Mind, Unaided Awareness (Brand Awareness) and Image (Brand Loyalty) significantly and positively affect stock return at $5 \%$ significance level.

Out of Brand Awareness ${ }^{7)}$ variables, unexpected

2007). The Hausman specification test revealed that the full model (equation (2') rejected the hypothesis with $\mathrm{H}$ of 34.3 ( $\mathrm{p}$ value .0001) and repeated the same results in other specifications.

6) We explain the results from the full model that includes all of the variables (eq. 7 in 〈Table 9〉).

7) Brand Awareness represents the ability of a buyer to identify a brand when purchasing the brand (Rossiter and Percy 1997). Top of Mind is a critical indicator that demonstrates how much the brand represents its category because it measures which brand comes to consumer's mind first in a particular category. For example, if consumers are asked which brand occurs to them first in the Cola Category, the majority of them would say "Coca-cola," the representative cola brand. Unaided Awareness, which includes Top of Mind brand, is an indicator measuring all the brands that are recalled in a specific category. Aided Awareness, on the other hand, is an indicator measuring whether consumers can recognize a brand when it is presented, regardless of whether a consumer know which product category the brand 
changes in Top of Mind and Unaided Awareness are positively and significantly related to stock returns. Unanticipated changes in Aided Awareness, on the other hand, do not have a significant relationship with stock returns. This empirically shows that marketing activities that increase Top of Mind and Unaided Awareness can play a critical role in enhancing the corporate's financial value. Despite the results, however, caution should be taken not to underestimate the importance of Aided Awareness when building up a new brand. Increasing Top of Mind and Unaided Awareness needs much time. Thus, when launching a new brand, marketing practitioners should endeavor to raise Aided Awareness. Image is composed of 'a high value for its price, 'uniqueness,' 'liveliness, and 'trustworthiness.' It's not certain which characteristics are related to brand asset value. Keller (2003) explains that 'strength,' 'favorability', and 'uniqueness' of brand associations in memory or brand image are the sources of brand equity. Although Image is not the same concept as brand image in Keller (2003), the two concepts have 'uniqueness' in common. We can interpret that 'uniqueness' might be one of the important characteristics of brand image constructing brand asset values. On the other hand, unanticipated changes in Purchase Intention and Preference that represent other loyalty indicators do not significantly provide additional explanatory power on accounting measures even if they are slightly related to stock returns.

In addition, we run a regression with the First Differencing (FD) model to remove fixed effects (See the Appendix for detailed model specification, equation (2")). The results of FD model are similar with those from the $\mathrm{FE}$ model as in Table 9. The only difference is the significantly positive relationship between the unanticipated changes in brand preferences and stock returns. This is consistent with Aaker and Jacobson (2001) that demonstrates the positive relationship between the unanticipated changes in brand attitudes and stock returns, although the result is supported only in the FD model, not in the FE model.

Aaker and Jacobson (2001) measure brand attitudes by subtracting the proportion of subjects with positive attitudes from the subjects with negative attitudes. The subjects are asked to choose among 'positive,' 'negative,' or 'no opinion' about specific brands. This measure is similar with the K-BPI brand preference measure in which the indicator asks whether the subjects or others like a brand, which can be interpreted as positive brand attitude. Brand attitudes are defined as overall evaluations of customers on brands (William L. Wilke 1994). Keller (2003) mentions that "Brand attitudes are

belongs to. For that reason, when the Unaided Awareness is much lower than the Aided Awareness of a brand, there is little possibility that the awareness of the brand leads to purchasing that brand. In short, Top of Mind and Unaided Awareness are much more important indicators than Aided Awareness in marketing practice. 
very important since they make basis of customers' actions and behaviors," which emphasizes the importance of brand attitudes. We can interpret that positive attitudes towards brands such as brand preferences are highly relevant to future profit propositions of the brands.

\subsection{Multicollinearity Test}

There is a possibility of multicollinearity that can be caused by highly correlated brand asset components. Thus, we examined whether there would be multicollinearity among variables by

〈Table 9〉 Regression Results (Fixed Effects Model)

\begin{tabular}{|c|c|c|c|c|c|c|c|c|}
\hline Variables & Eq.1 & Eq.2 & Eq.3 & Eq.4 & Eq. 5 & Eq. 6 & Eq.7 & Eq. 8 \\
\hline mv(t-1) & $-36^{* *}(-2.45)$ & $-3.37^{* *}(-2.53)$ & $-.34^{* *}(-2.27)$ & $-.44^{* * *}(-3.03)$ & $-34^{* *(-2.14)}$ & $-.38 * * *(-2.68)$ & $-.42^{* * *}(-2.88)$ & $-.37 *(-2.52)$ \\
\hline $\operatorname{bmv}(t-1)$ & $.20(1.05)$ & $.18(.92)$ & $.22(1.14)$ & $.16(.82)$ & $.20(1.07)$ & $.16(.87)$ & $.12(.63)$ & $.20(1.04)$ \\
\hline $\mathrm{U} \triangle \mathrm{ROA}$ & $1.72^{* *}(2.35)$ & $1.69 * *(2.32)$ & $1.75^{* *}(2.39)$ & $1.69^{* *}(2.37)$ & $1.74^{* *}(2.44)$ & $1.72^{* *}(2.46)$ & $1.58^{* *}(2.26)$ & $1.66 * *(2,28)$ \\
\hline$\Delta$ Sales & $.15(.91)$ & $.15(.91)$ & $.17(.99)$ & $.08(.48)$ & $.20(1.19)$ & $.13(.78)$ & $.13(.78)$ & $.13(.75)$ \\
\hline$\Delta$ top of mind & & $.02^{*}(1.77)$ & & & $.04^{* * *}(3.48)$ & $.04^{* * *}(3.19)$ & $.04^{* * *}(2.99)$ & \\
\hline$\Delta$ unaided & & & $.01(1.20)$ & & $.02 * *(3.43)$ & $.02^{2 * *}(3.09)$ & $.02 * *(2.23)$ & \\
\hline$\triangle$ aided & & & & & & & $.005(.73))$ & $.01(1.56)$ \\
\hline$\Delta$ image & & & & $.04^{* * *}(3.32)$ & & $.03^{* * *}(3.05)$ & $.04^{* * *}(2.68)$ & \\
\hline$\Delta$ purchase & & & & & & & $-.02(-1.25)$ & $.002(.12)$ \\
\hline$\Delta$ preference & & & & & & & $.007(.83)$ & $.01(1.16)$ \\
\hline No. of obs & 246 & 246 & 246 & 246 & 246 & 246 & 246 & 246 \\
\hline Adj. R2 & .14 & .15 & .14 & .173 & .18 & .207 & .215 & .160 \\
\hline
\end{tabular}

Notes: 1) Dependent Variable - str(stock return)

2 ) $* * * * * *$ - significant at the $10 \%, 5 \%$ and $1 \%$ level, respectively

〈Table 10〉 Regression Results (First Differencing Model)

\begin{tabular}{|c|c|c|c|c|c|c|c|c|}
\hline Variables & $\begin{array}{r}\text { Eq.1 } \\
\end{array}$ & Eq.2 & Eq.3 & Eq.4 & Eq.5 & Eq.6 & Eq.7 & Eq.8 \\
\hline$m v(t-1)$ & $-.74 * *(-3.55)$ & $-.74^{* *}(-3.56)$ & $-0.73 *(-3.50)$ & $-0.76^{* * *}(-3.73)$ & $-0.73 * * *(-3.54)$ & $-.73 *(-3.56)$ & $-.76 * * *(-2.88)$ & $-.72 * *(-3.44)$ \\
\hline $\operatorname{bmv}(t-1)$ & $.50^{* *}(2.12)$ & $.49^{* *}(2.06)$ & $0.50^{* *}(2.10)$ & $0.43^{*}(1.84)$ & $.51^{* *}(2.17)$ & $.42^{*}(1.79)$ & $.36(1.52)$ & $.51 * *(2.13)$ \\
\hline $\mathrm{U} \triangle \mathrm{ROA}$ & $1.21 *(1.67)$ & $1.19(1.63)$ & $1.23^{*}(1.69)$ & $1.28^{*}(1.80)$ & $1.28 *(1.77)$ & $1.30 *(1.82)$ & $1.29^{*}(1.67)$ & $1.26(1.72)$ \\
\hline$\Delta$ Sales & $-.02(-.15)$ & $-.02(-.13)$ & $-.02(-.12)$ & $-.08(-.51)$ & $-.06(-.38)$ & $-.06(-.39)$ & $-.03(-20)$ & $-.04(-.27)$ \\
\hline$\Delta$ top of mind & & $.008(1.10)$ & & & & $.02^{* *}(2.14)$ & $.02^{* *}(2.01)$ & \\
\hline$\Delta$ unaided & & & $.004(.8)$ & & & $.012^{*}(1.90)$ & $.02^{* *}(2.01)$ & \\
\hline$\Delta$ aided & & & & & & & $-.005(-.85)$ & $.004(.72)$ \\
\hline$\Delta$ image & & & & $.024^{* * *}(2.76)$ & & $.014(1.44)$ & $.03^{* *}(2.12)$ & \\
\hline$\Delta$ purchase & & & & & & & $-.02^{*}(-1.81)$ & $.008(.80)$ \\
\hline$\Delta$ preference & & & & & $.013^{* *}(2,34)$ & $.01(1.56)$ & $.02^{* *}(2.15)$ & \\
\hline No. of obs & 246 & 246 & 246 & 246 & 246 & 246 & 246 & 246 \\
\hline Adj. R2 & .347 & .349 & .348 & .369 & .361 & .382 & .388 & .348 \\
\hline
\end{tabular}

Notes: 1) Dependent Variable - str(stock return)

2) $*, * *, * * *$ - significant at the $10 \%, 5 \%$ and $1 \%$ level, respectively 
running ordinary least squares regression and checked the collinearity statistics. 〈Table 11〉 shows that every variance influential factor (VIF) is under 10. If VIF value is over 10, it is considered that there is multicollinearity (Park 2007; Rawlings, Pantula and Dickey 1998).

The results show that Aided Awareness, Purchase Intention and Preference don't have significant effect on stock return in equation 7 of FE model and Aided Awareness and Purchase Intention don't have significantly positive relationship with stock return in equation 7 of $\mathrm{FD}$ model. However, due to highly correlated variables or multicollinearity, those variables may have insignificant impact on stock return. To check the issue, we estimated another model with Aided Awareness, Purchase Intention and Preference (just in FE model) excluding significant variables. Equation 8 in each model shows that those variables also don't influence stock return significantly, which confirms our results.

〈Table 11〉 collinearity statistics

\begin{tabular}{ccc}
\hline variables & Tolerance & VIF \\
\hline \hline$\triangle$ top of mind & .527 & 1.896 \\
$\triangle$ unaided & .392 & 2.549 \\
$\triangle$ purchase & .537 & 1.861 \\
$\triangle$ image & .581 & 1.720 \\
$\triangle$ preference & .581 & 1.721 \\
$\triangle$ aided & .563 & 1.776 \\
$\triangle$ Sales & .888 & 1.126 \\
$\mathrm{U} \triangle \mathrm{ROA}$ & .947 & 1.056 \\
$\mathrm{mv}(\mathrm{t}-1)$ & .834 & 1.199 \\
$\mathrm{bmv}(\mathrm{t}-1)$ & .845 & 1.183 \\
\hline
\end{tabular}

\subsection{Product Brand vs. Service Brand}

Additionally, we investigated whether there are any differences of financial effects of brand components between tangible product industry and intangible service industry (Yi 2006). We divided the dataset into product (19brands) and service (30brands) brands and fitted FE model and FD model respectively.

$\langle$ Table 12〉 shows the interesting results. From FE model and FD, we found that Unanticipated changes of Brand Awareness components (Top of Mind and Unaided Awareness) have significant effects on changes of Stock Return but unexpected changes of Brand Loyalty components (except for Preference in FD Model) don't. On the other hand, unanticipated changes of Brand Image and Preference (just in FD model) which are Brand Loyalty components are significantly associated with changes of Stock Return and Brand Awareness components are not. In other words, information from changes of Brand Awareness positively affects the expectations of stock market participants on tangible product brands and information from variation of Brand Image and Preference are positively correlated with stock return of intangible service brands.

From those results, we can explain that just increasing brand awareness can give positive signals to the stock market in tangible products brands. However, service industries should not just make consumers be aware of their 
brands but also make them get better image and attractiveness of their brands to improve future financial profits in the stock market.

Previous papers on service branding emphasize that brand building is more critical for service companies than product companies because most service consumption happens regularly, and powerful brands obtain consumers' trust and make them get secure in buying intangible service (Berry 2000; He and Li 2001). 'Intangibility' of service brands is highly associated with perceived risk, thus intangible services make consumers perceive more risk than tangible products do by increasing the degree of uncertainty, which affects consumer expectations of service quality (Finn 1985; Guseman 1981; McDougall and Snetsinger 1990; Mitchell and Greatorex 1993; Murray and Schlacter 1990). Although it's not easy to separate ques- tions affecting Stock Return from related questions in $\langle$ Table 4〉, it might be interpreted that 'value for price', 'trustworthiness' and 'preference' are related to reduce consumers' perceived risk to consuming intangible service brands.

For generalizable results, however, it is necessary to have more empirical analysis by using more data and related discussions. And study on the differences of the financial impacts of brand components among more segmented industries will be a meaningful research topic.

\section{Conclusion}

\subsection{Conclusion and Implications}

We investigated the relationship between

〈Table 12〉 Panel Regression Models_Product Brands vs. Service Brands

\begin{tabular}{|c|c|c|c|c|}
\hline Variables & $\mathrm{FE}-\mathrm{PB}$ & FE-SB & FD-PB & FD-SB \\
\hline $\mathrm{mv}(\mathrm{t}-1)$ & $-.24(-.88)$ & $-.42^{* *}(-2.34)$ & $-.72 *(-1.9)$ & $-.74^{* * *}(-3.11)$ \\
\hline $\operatorname{bmv}(t-1)$ & $.31(.96)$ & $.12(.47)$ & $.15(.37)$ & $.53^{*}(1.80)$ \\
\hline $\mathrm{U} \triangle \mathrm{ROA}$ & $1.96 *(1.96)$ & $1.23(1.24)$ & $1.38(1.36)$ & $1.04(1.00)$ \\
\hline$\triangle$ Sales & $.24 .82)$ & $.04(.19)$ & $.15(.56)$ & $-.1(-.51)$ \\
\hline$\triangle$ top of mind & $.06^{* *}(2.59)$ & $.02(1.20)$ & $.03 * *(2.05)$ & $.01(.79)$ \\
\hline$\triangle$ unaided & $.04^{* *}(2.51)$ & $.005(.42)$ & $.03^{* *}(2.11)$ & $.01 \quad(.69)$ \\
\hline$\triangle$ aided & $-.002(-.15)$ & $-.001(-.15)$ & $-.007(-.56)$ & $-.005(-.67)$ \\
\hline$\triangle$ image & $.02(.76)$ & $.05^{* * *}(2.82)$ & $.009(.45)$ & $.03^{* *}(2.36)$ \\
\hline$\triangle$ purchase & $.03(.75)$ & $-.02(-1.00)$ & $.03(.9)$ & $-.02 *(-1.88)$ \\
\hline$\triangle$ preference & $-.06(-1.62)$ & $.01(.77)$ & $-.05(-1.66)$ & $.02 * *(2.26)$ \\
\hline No. of obs & 102 & 144 & 102 & 246 \\
\hline Adj. R2 & .26 & .22 & .33 & .38 \\
\hline
\end{tabular}

Notes: 1) Dependent Variable - str(stock return)

2) $* * *, * * *$ - significant at the $10 \%, 5 \%$ and $1 \%$ level, respectively

3) PB - Product Brand, SB - Service Brand 
brand asset values created by marketing activities and market value in the financial market to prove the monetary value of intangible marketing assets. Using not only brand equity data from the $\mathrm{K}-\mathrm{BPI}$, but also accounting and financial market data, we found that some brand asset components have explanatory power on stock returns.

The study reveals that unanticipated changes in 'Top of Mind', 'Unaided Awareness', 'Brand Image' and 'Preference (just in the FD model)' significantly and positively affect stock returns. Changes in the other two variables do not have significant effects (Aided Awareness, Purchase Intention). In other words, stock market participants respond to unexpected changes in 'Top of Mind,' 'Unaided awareness,' 'Brand Image, and 'Preference' and reshape their expectations on the corresponding brands, which leads to an increase in the corresponding stock prices.

Although there is a statistically significant relationship between stock returns and independent variables, the correlation does not imply causality (See Mizik and Jacobson (2008) for details). In other words, stock market investors respond to information incorporated in the $\mathrm{K}$ BPI data rather than to the K-BPI data itself.

The following are key contributions and implications of this study. First, using a unique $\mathrm{K}$-BPI data set, we have proved that some brand components, such as 'Top of Mind,' 'Unaided awareness,' 'Image, and 'Preferences' are fi- nancially valuable. Needless to say, they are important and well-established brand components in affecting brand attitude or purchase intention. However, our research purpose is not to prove that those brand components are just crucial in brand attitude or purchase intention, but to show that they are financially valuable asset components in stock markets. Srinivasan and Hanssens (2009) said "the marketing profession is being challenged to assess and communicate the value created by its actions on shareholder value. These demands create a need to translate marketing resource allocations and their performance consequences into financial and firm value effects." One of the marketing's main contributions is to build intangible brand equity which is time consuming. Thus, because financial outcomes of brand equity might be fairly delayed, the investor community should view marketing spending not as just costs but as a long-term investment. For example, the term of chief marketing officers (CMO) is relatively shorter than that of the other senior executives (Peppers and Rogers 2005), which demonstrates that CMO's performance falls short of expectations chief executives and boards of directors who are anticipating immediate marketing results. The results of this paper can be helpful to firms in pursuing not just short-term perspective of marketing actions but also long-term marketing performance. The results of this paper can be helpful to firms in pursuing not just short- 
term perspective of marketing actions but also long-term marketing performance.

Second, the need for public announcements on changes in brand asset value to stock market participants is strengthened by this study since PR and IR managers would be able to realize the financial value of brand assets by their activities. For a long time, there has been controversy over whether financial statements should reflect brand value. Consequently, only a few countries such as the United Kingdom and Australia reflect brand asset value on financial statements (Kallapur and Kwan 2004). We empirically proved that brand asset components and firm value are positively correlated, which reconfirms the results of related previous studies. Intangible assets such as knowledge and brand are accounting for more and more of the firm's values. Therefore, there will be a growing need for firms to manage brand assets systematically and officially announce the trends of the intangible assets with other tangible asset value periodically, which would be beneficial for the investors of the firms.

\subsection{Limitations and Future Research}

The contributions and implications of this study do not dilute some limitations, which shed light on future studies. The followings are limitations and future research directions.

First, we restricted brands which satisfy both requirements, monobrands and stock market listed brands, to investigate the relationship with share prices. Thus, we analyzed only 49 brands among the K-BPI brands, which are over 2,000, therefore, cannot generalize the research results to all of the K-BPI brands.

Second, although the K-BPI categorize data into consumer packaged goods, durable goods, and service industry data, the limited number of observations do not allow this study to make a separate analysis that might produce different results depending on industries. Future studies with sufficient number of observations would address this issue.

Lastly, share prices have limitations to measure financial value and to be selected as a dependent variable. Stock prices are attributed to long-term performances, future-oriented and accumulated financial value. Anderson, Fornell and Mazvancheryl (2004) argue that "Stock prices are not standardized criteria for firm-level and industry-level analysis." Brand equity contributes not only to future profits but also to current firm value such as sales. Placing emphasis on just the relationship between stock returns and brand asset components may underestimate the current value of brand assets. Yi and Lee (2006) examine the relationship between customer satisfaction and firm value by using the Economic Value Added - EVA as a dependent variable that represents firm value. The EVA is well-regarded by Stewart (1994) since it uses risk-adjusted discount rates on invested capital and minimizes biases in ac- 
counting indices. Hence, future analysis on multilateral relationships among brand asset value, profit rates and firm value would help reveal the relationship between brand assets and the firm's financial value.

〈Received August 23. 2013〉

〈1st Revised October 8. 2013〉

〈2nd Revised November 20. 2013〉

〈Accepted March 24. 2014〉

\section{References}

Aaker, David A. (1996), Building Strong Brands, New York: The Free Press. (2004), Brand Portfolio Strategy, New York: The Free Press. and Robert Jacobson (1994), "The Financial Information Content of Perceived Quality," Journal of Marketing Research, 31(May) 191-201 and (2001a), "The Value

Relevance of Brand Attitude in HighTechnology Markets," Journal of Marketing Research, 38(November), 485-93. and Erich Joachimsthaler (2000), Brand Leadership, York: The Free Press.

Ailawadi, Kusum L., Donald R. Lehmann, and Scott A. Neslin (2003), "Revenue Premium as an Outcome Measure of Brand Equity," Journal of Marketing, 67(October), 1-17. Anderson, Eugene W., Class Fornell and Sanal
K. Mazvancheryl (2004), "Customer Satisfaction and Shareholder Value," Journal of Marketing, 68(October), 172-85.

Ball, Ray and Philip Brown (1968), “An Empirical Evaluation of Accounting Income Numbers," Journal of Accounting Research, 6(Autumn), 159-78.

Barth E. Mary, Clement B. Michel, Foster George, and Kasznik Ron (1998), "Brand Values and Capital Market Valuation," Review of Accounting Studies, 3, 41-68.

Berry, Leonard L. (2000), "Cultivating Service Brand Equity," Journal of Academy of Marketing Science, 28(1), 128-37.

Daniel, Kent and Sheridan Titman (2003), "Market Reaction to Tangible and Intangible Information," National Bureau of Economic Research Working Paper Series No. 9743.

Doyle, Peter (2001), "Building Value-based Branding Strategies," Journal of Strategic Marketing, 9(4), 255-68.

Easton, P. D., and T. S. Harris (1991), "Earnings as an Explanatory Variable for Returns," Journal of Accounting Research, 29(1), 19-36.

Eberhart, Allan C., William F. Maxwell, and Akhtar, Siddique (2004), "An Examination of Long-Term Abnormal Stock Returns and Operating Performance Following R\&D Increases," Journal of Finance, 59(April), 623-50.

Fama, Eugene (1998), "Market Efficiency, Long- 
Term Returns, and Behavioral Finance," Journal of Financial Economics, 49(3), 283306.

and Keneth R. French (1993), "Common Risk Factors in Returns to Stocks and Bonds," Journal of Financial Economics, 33 (1), 3-56.

and Keneth R. French (1996), "Multifactor Explanations of Asset Pricing Anomalies," Journal of Finance, 51(March), 55-84.

Finn, A. (1985), “A Theory of the Consumer Evaluation Process for New Product Concept," Research in Consumer Behavior, 1, 33-65.

Guseman, D. S. (1981), "Risk Perception and Risk Reduction in Services," in Marketing of Services, Donnelly, J. H. and W. R. George, eds. Chicago: IL, American Marketing Association, 588-601.

He, Hongwei and Yan Li (2011), "CRS and Service Brand: The Mediating Effect of Brand Identification and Moderating Effect of Service Quality," Journal of Business Ethics, 100(4), 673-88.

Johnston, Jack and Dinardo, John (2007), Econometric Methods, $4^{\text {th }}$ ed., McGraw-Hill.

Jun, Sung-Youl and Park, Chan Su (2010), "Ten Years of Research on Brands: Research Findings and Future Priorities," Journal of Consumer Studies, 21(June), 141-91.

Kallapur, Sanjay and Sabrina Y. S. Kwan
(2004)," The Value Relevance and Reliability of Brand Assets Recognized by UK Firms," Accounting Review, 79 (January), 151-72.

Keller, Kevin L. (2003), Strategic Brand Management: Building, Measuring, and $\mathrm{Ma}^{-}$ naging Brand Equity, $2^{\text {nd }}$ ed., Upper Saddle River, NJ:Prentice-Hall.

Kormendi, Roger and Lipe, Robert (1987), "Earnings Innovations, Earnings Persistence and Stock Returns," Journal of Business, 60(3), 324-45.

Kothari, S.P. (2001), "Capital Markets Research in Accounting," Journal of Accounting and Economics, 31(September), 105-231.

LeRoy, Stephen (1989), "Efficient Capital Markets and Martingales," Journal of Economic Literature, 27(December), 1583-1621.

McDougall, G. H. G and Snetsinger, D. W. (1990), "The Intangibility of Services: Measurement and Competitive Perspectives," Journal of Services Marketing, 4(4), 27-40. Miller, Merton and Kevin Rock (1985), "Dividend Policy Under Asymptotic Information," Journal of Finance, 40(4), 1031-51.

Mitchell, V. W. and Greatorex, M. (1993), "Risk Perception and Reduction in the Purchase of Consumer Services," The Services Industries Journal, 13(4), 179-200.

Mizik, Natalie and Robert Jacobson (2004), "Stock Return Response Modeling," in Assessing Marketing Strategy Performance, Christine Moorman and Donald R. Lehmann, eds. 
Boston: Marketing Science Institute, 29-46. and (2008), “The Financial

Value Impact of Perceptual Brand Attributes," Journal of Marketing Research, 45 (1), 15-32.

Murray, K. B. and Schlacter, J. L. (1990), "The Impact of Services versus Goods on Consumers' Assessment of Perceived Risk and Variability," Journal of the Academy of Marketing Science, 18(1), 51-65.

Oh, Yun Kyung (2013), "Informative Role of Marketing Activity in Financial Market: Evidence from Analysts' Forecast Dispersion," Asia Marketing Journal, 15(October), 53-77. Ohlson, J. (1995), "Earnings, Book Values and Dividends in Security Valuation", Contemporary Accounting Research, 12, 661-87.

Park, Moon Ki (2003), Brand Equity Evaluation, Good Morning Media.

Park, Sung-Hyun (1998), Regression Analysis, Minyoungsa.

Rawlings, John O., Sastry G. Pantula, and David A. Dickey (1998), Applied Regression Analysis, $2^{\text {nd }}$ ed., Springer.
Rust, Roland T., Katherine N. Lemon, Valarie A. Zeithaml (2004), "Return on Marketing: using customer equity to focus marketing strategy," Journal of Marketing, 68(1), 109-27.

Srivastava, Rajendra K., Tasadduq A. Shervani, and Liam Fahey (1998), "Market-Based Assets and Shareholder Value: A Framework for Analysis," Journal of Marketing, 62(January), 2-18.

Stewart, G. B. (1994) "Fact and fantasy," Journal of Applied Corporate Finance, 7 (Summer), 71-84.

Webster, Frederick E., Alan J. Malter and Shankar Ganesan (2005), "The Decline and Dispersion of Marketing Competence," MIT Sloan Management Review, 46(4), 35-43.

Wilke, William L. (1994), Consumer Behavior, $3^{\text {rd }}$ ed., New York: John Wiley.

Yi, Youjae (2006), Service Marketing, $3^{\text {rd }}$ ed., Hakhyunsa. and Lee, Cheonglim (2006), "The Effects of Customer Satisfaction on Firm's Profitability and Value," Journal of Korean Marketing Association, 21(2), 85-113. 


\section{$\langle$ Appendix〉}

Fixed-Effects (FE) model:

The dependent variable is stock return (STR) as in equation (2). The empirical equation (2) can be set forth in detail as the following.

$$
\begin{aligned}
S T R_{i t}= & \sum_{t=2002}^{2008} \alpha_{1 t} \times \text { Year }_{t}+\sum_{t=2002}^{2008}\left(\alpha_{2 t} \times \log M V_{i t-1}+\alpha_{3 t} \times \log B M V_{i t-1}\right) \times \text { Year } \\
& +\varphi_{1} U \Delta R O A+\varphi_{2} U \Delta \text { sales }+\beta_{1} \Delta \text { tom }+\beta_{2} \Delta \text { unaided }+\beta_{3} \Delta \text { aided } \\
& +\beta_{4} \Delta \text { image }+\beta_{5} \Delta \text { purchase }+\beta_{6} \Delta \text { preference }+\varepsilon_{i t}
\end{aligned}
$$

$\triangle$ is the difference between the value of the previous period and that of the current period. $U \triangle R O A$ $\Delta$ sales, $\Delta$ tom, $\Delta$ unaided, $\Delta$ aided, $\Delta$ image, $\Delta$ purchase, and $\Delta$ preference are unanticipated changes in ROA, Sales Growth(accounting measures), Top of Mind, Unaided Awareness, Aided Awareness, Image, Purchase Intention, and Preference (brand asset measures), respectively.

First Differencing (FD) Model:

Time-invariant individual effects $\mu_{i}$ in equation (2) can be removed by differencing. (2) is firstdifferenced into equation (2")

$$
\begin{aligned}
d S T R_{i t}= & \sum_{t=2002}^{2008}\left(\alpha_{2 t} \times d \log M V_{i t-1}+\alpha_{3 t} \times d \log B M V_{i t-1}\right) \times \text { Year }_{t} \\
& +\sum_{j=1}^{J} \varphi_{j} d U \Delta A c P_{j i t}+\sum_{k=1}^{K} \beta_{k} d U \Delta \text { Brandasset }_{k i t}+\Delta v_{i}
\end{aligned}
$$

$d$ represents the differencing operator. $\Delta \nu_{i}$ is $\varepsilon_{i t}-\varepsilon_{i t-1}=\left(\mu_{i}+v_{i t}\right)-\left(\mu_{i}+v_{i t-1}\right)=v_{i t}-v_{i t-1}$. 